\title{
The forming of regional identity and identity of regions in Czechia - introduction to the research on the impact of second housing and tourism
}

\author{
DANA FIALOVÁ ${ }^{1}$, PAVEL CHROMÝ ${ }^{1}$, ZDENĚK KUČERA $^{1}$, JANA SPILKOVÁ ${ }^{1}$, \\ P̌̌EMYSL ŠTYCH ${ }^{2}$, JIŘÍ VÁGNER ${ }^{1}$ \\ ${ }^{1}$ Charles University in Prague, Faculty of Science, Department of Social Geography \\ and Regional Development \\ 2 Charles University in Prague, Faculty of Science, Department of Applied Geoinformatics \\ and Cartography
}

\begin{abstract}
The article develops general theoretical discussion on researches on second housing as well as concepts of the new regional, new cultural and behavioral geographies. The major focus is given on theoretical and methodological background of the process of formation of regional identity and identity of regions in the areas with considerable concentration of settlements and municipalities with prevailing tourist function. It deals with identification of the inner development potential of localities and regions from socioeconomic and sociocultural views. Both identity of regions (their outer and inner image) and appurtenance of residents and tourists (second home owners) with the territory is emphasized. The key objective is to support and explain possible behavioral approaches in the research of the impact of second housing and tourism activities in the forming of regional identity and identity of the regions.
\end{abstract}

Key words: regional identity, identity of regions, second housing, tourism, behavioral approaches

\section{Introduction}

Identity is the way which either individual or the group of individuals define themselves, feel their existence (uniqueness) and which support their consciousness in the relation to others. Identity can have a number of forms mutually overlapping or complementing. The spatial (geographical) aspect is one of the aspects represented in the identity forming process. The people's relation to their region is a natural part of their lives (Chromý, Janů 2003). Particular territory with specific social, economic or developmental conditions (with specific historical development) serves as a base for forming of territorial/regional identity. Natural conditions as well as the landscape resulting from the interaction of man and nature can also play a key role in forming of the regional identity (Black, Butlin 2001; Graham, Nash eds. 2000; Tuan 2001). Research on identity has become one of six pillars of the new regional geography in last few decades (Chromý 2004a; Mitchell 2004; Paasi 1986) and a subject of cultural geography (e.g. Gesler, Kearns 2002; Nash 2002, 2003) and historical geography (Baker 2003; Graham 2000; Graham, Nash eds. 2000; Holdsworth 2002 etc.). The article is not an analytic study but presents a theoretical outline of the up-to-date research agenda in the field with a brief 
explanation of proposed methods. The objective is to support and explain possible behavioral approaches in the research of the impact of second housing and tourism activities in the forming of regional identity and identity of the regions.

\section{Regional identity and identity of regions}

Several principles of identity, thus ways people use places for own identity forming, can be distinguished (Gustafson 2001):

1. The principle of differentiation of ourselves from others on the basis of the place we are living in (a separate problem is the border delimitation of this place/territory).

2. The consciousness of our own life continuity that we have lived through at the same place for a long time or we have moved from a similar place contributes to defining of ourselves.

3. The principle of self-esteem when we have feeling of the pride of the place we are living at.

4. The place can to some extent contribute to self-efficacy through its qualities. These principles concern individual identity and also individual space category - place. Besides individual/local identity we can speak about the above mentioned collective (regional) identity also about identity of regions.

Research on regional identity of inhabitants is an innovative and so far not sufficiently handled theme in Czechia. Regional consequences of globalization, integration and transforming processes are studied predominantly with the stress on social and economic aspects - mostly analyses of "hard" and relatively easy available data in Czechia (see e.g. Hampl et al 1996; Hampl et al 2001). Aspects of sociocultural character ("soft" factors - identity, attitudes of inhabitants, civic society, culture and so on) are on the margin of interest on the contrary to e.g. Anglo-Saxon world. And even in spite of the fact that connections of development of mainly problematic regions with "human" potential of the region (relation of inhabitants to the territory, solidarity with the region and regional communities, the process of image making of regions - both from outside and inside, the role of culture etc.) have been clearly proved. In the Czech geography the identity of inhabitants in the relation to regions is dealt with particularly by geographers in Ostrava and Brno (thus historical Moravia and Silesia lands). Identities of lower territorial units, natural cultural regions are described by e.g. Vencálek (1988), Daněk at the historic land level (1993, 2002) and Siwek (1996, 1999), Siwek and Kaňok (2000) and in discussion also Chromý (2003, 2004b), Rehák (1998), Vaishar (2004) an others. Research on regional identity of inhabitants has gained interdisciplinary character. Even Czech sociology is not comprehensively engaged in the issue of human identity or group identity except only e.g. Havelka et al. (2002) and Zich ed. (2003).

The "sense" of place has been and often is attributed to the space (on different hierarchical levels: place/locality - micro-region - region). Leaving out the meaning of the state territory and borders for forming national and state identity, regional/territorial identity and the relation to the place can play a role even in regional development of smaller territorial units - administrative, cultural, border regions etc. - 
see Fig. 1 (questionnaire of 175 secondary school teachers from all administrative regions in Czechia).

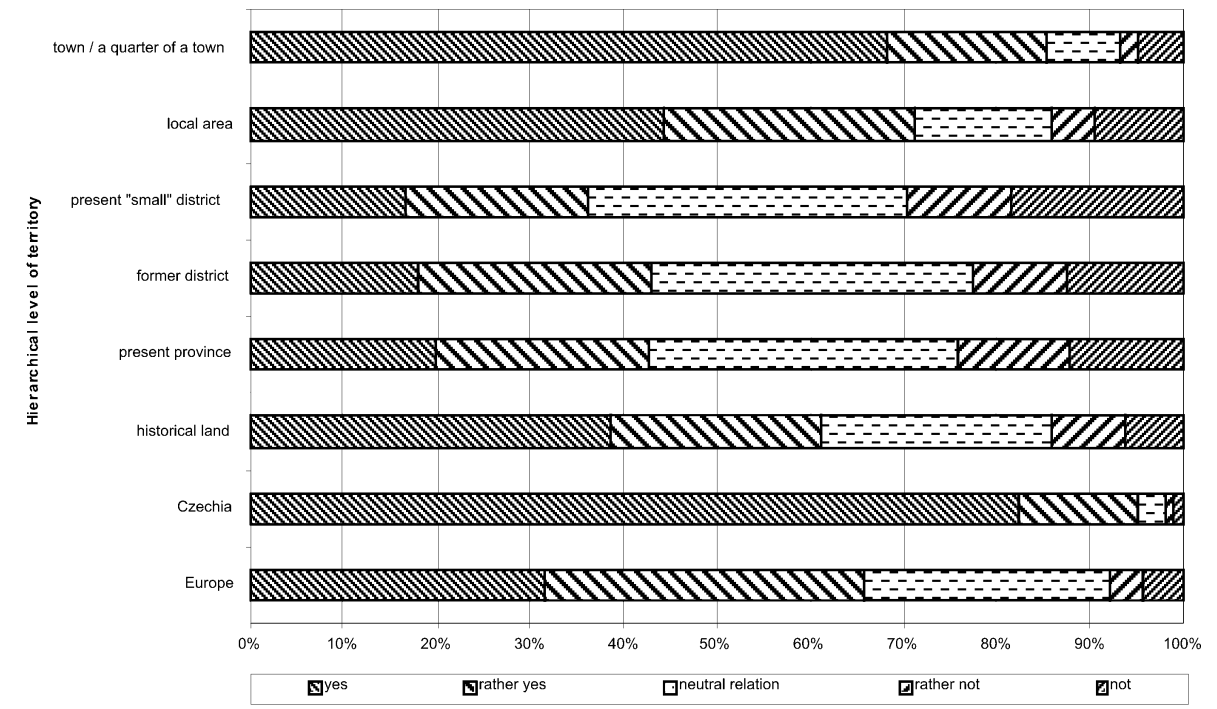

Fig. 1 Individual perception of regional identity in relation to hierarchical level of territory ("I feel myself above all an inhabitant of...")

Source: Chromý, Kučerová, Kučera 2009

Identity of regions can be perceived on two levels: subjective and objective one. The subjective level involves images of inhabitants and individuals living out of region (we speak also about regional consciousness). The objective level reflects the classifications created in the sphere of different scientific disciplines based on division of labor, commuting, physic-geographical conditions etc.

Regions are changing (developing) in time in the same way as the development of the society which creates them and as the landscape which is reshaped by the society. The base for formation of the territorial identity of population is both relations to the territory and time embedding. Another separate issue is the delimitation of the territory which is a subject of identification. Different types of boundaries can be understood: physical (physic-geographical, administrative, state etc.), cultural boundaries (societal in the broader context), symbolic etc. These boundaries (mostly those historicgeographical ones, Chromý, 2000) as well as pushing national identity at the state level may cause conflicts with identities of the smallest territorial units (historical lands, cultural regions, ethnically homogenous areas, national minority areas etc.). A complex approach to the rise of a region is defined in the institutionalization of regions (Paasi 1986). "Institutionalization of a region is a socio-spatial process of the rise of a spatial unit as a component of socio-spatial structure which can be clearly identified in various spheres of social practice and social awareness" (Paasi 1986, p. 121). Important elements for formation of the regions are individual initiative, 
image of the region (inner and outer), the name of the region, creation of institutions and regional symbols, educational system, regional literature, media (mostly daily newspapers) etc.

For all regions (at different hierarchical levels - either a town or a state) four stages of the institutionalization process can be declared. The rank of stages might be different, they often run simultaneously. The first stage is defined with getting a spatial form. Then Paasi (1986) declares forming of symbolic contours followed with development of institutions and the last phase - embedding of region as a part of regional system and regional consciousness of the society. In the meanwhile regional identity was built up with different extension and in different way during the stages. Paasi (2002) identifies "basic stones" of the territorial identity formed in this process.

Several types of regional identity can be distinguished from the developmental point of view:

a) Regions that have gained sovereignty and the identity forming have followed. The Vysočina or the Moravskoslezský (Moravian-Silesian) provinces can stand as examples among new provinces - both territories are separated by traditional identity with historical lands and historic-geographical borders are still perceptible in the minds of inhabitants (1996, 1999; Chromý 2000; Siwek, Kaňok 2000; Zeman 2001, Chromý, Janů 2003 and others). Perception of regional identity of secondary teachers (175) in administrative regions of Czechia is illustrated in Fig. 2. The index represents the share of positive ("yes") answers to 11 questions on pride of different regional aspects (environment, history, architecture, lively tradition, sport and others).

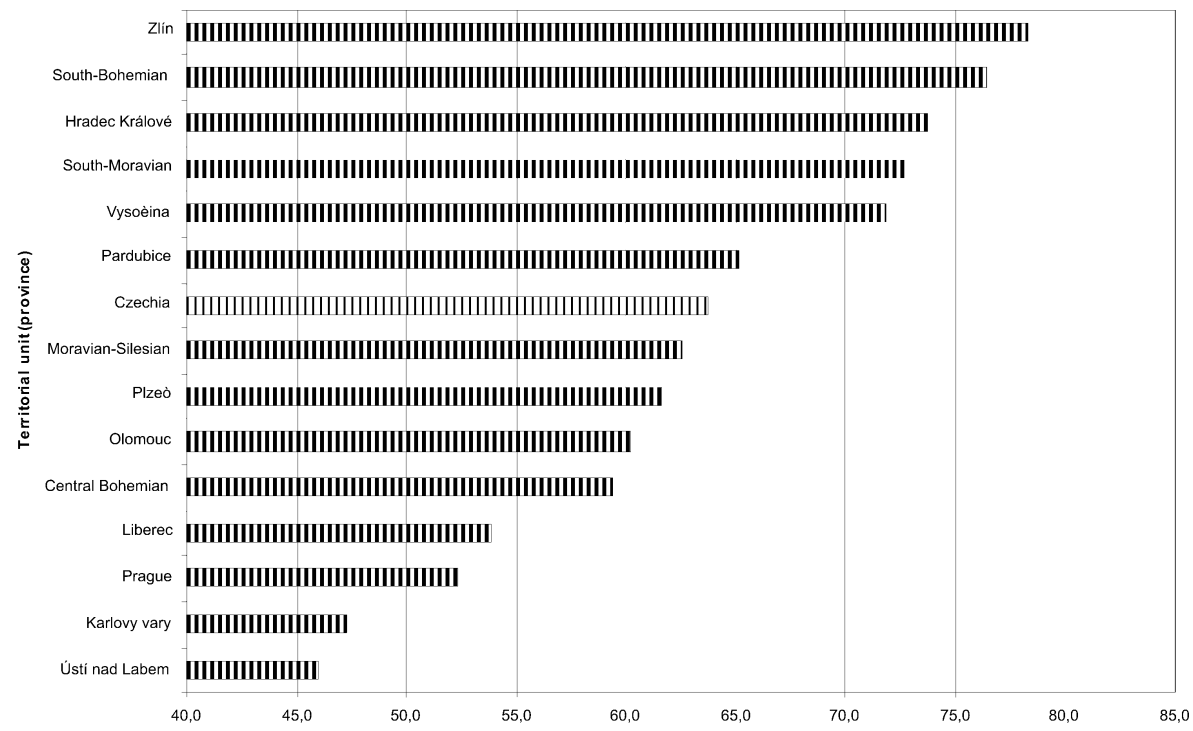

Fig. 2 The index of regional identity of secondary teachers in individual regions of Czechia Source: Heřmanová, Chromý et al. 2009 
b) Regions with traditional regional sense (regional identity) that have not gained full sovereignty and institutional system of which has not been completed. For example, traditional cultural regions in Czechia - Chodsko, Valašsko, Slovácko and others (Vencálek 1998).

c) Regions with "lost" identity that can be divided into two groups. The first group the areas formed on the basis of national consciousness in the $19^{\text {th }}$ century (e.g. Podřipsko) that have lost their dominant ideological function. The other group comprises areas of borderlands with removed inhabitants after World War II by the expulsion of the Czechoslovak Germans to Germany (Kučera 2007), which have lost identity holders (local people). The identity of Czech borderlands (till the year 1945) remarkably lives on abroad. Regional identity of present inhabitants of these borderlands thus gets into the imaginary "conflict" with the original identity of transferred inhabitants.

d) Regions "seeking" identity, partly or purposely institutionalized. Those are mainly the areas with existing purpose micro-regional associations of municipalities using predominantly in names traditional regional consciousness (Český Merán, Podblanicko, Horácko), today however in a different state than they used to have in the $19^{\text {th }}$ century. Regional population is linked together with so-called anticipated structures - ways to view and assess events influenced with the residential territory.

In the conclusion of the institutionalization analysis should be pointed out that formation of a region is not the end of the process which can be transformed in the extent, importance etc. Extinction can be observed as well because the rise of another new region leads to a change in former spatial order and to de-institutionalization of former regions. The territorial identity may be understood as unity and conformity, harmony of human behavior in the territory and time (Paasi 1986). Real inward and experienced regional consciousness (sense) presents only one component of a multidimensional phenomenon and limited focus given only on this dimension would mean a clear simplification (Vencálek 1998).

With the respect to M. Hampl's statement (2003) about qualified delimitation of community level as an autonomous structure in the framework of regional organization levels (in case of communities with at least some extent of regional selfidentification), necessity for regional identity and identity of regions research seems to be a topical and desirable theme.

\section{Territorial identity, tourism and second housing}

When analyzing the definition of the territorial identity (Passi 1986, see above), proper understanding of key term "a complex of population in the particular territory" is essential. It is evident this complex is mostly made up of residents with different roles (self-government representatives, entrepreneurs, civic association members, common citizens...). On the other side there are regions where this complex is supplied (with different intensity, periodicity, seasonally, over weekends and holidays) with temporary dwellers with strong regional bonds and identification. A typical group 
is represented in our country by owners and users of second homes (Librová 1996a, b, Fialová 2000, Bičík 2001, Duffková 2002, Roberts 2002, Vágner, Fialová et al. 2004, Cílek 2007), with strong relationship and heritage bonds to the dwellings and sites of their ancestors. Second homes tradition has influenced many generations and some second home dwellers feel deeper relations and identification with the place of leisure activities than with their place of residence, even deeper than autochthons. Second homes in Czechia cover $20 \%$ of all dwellings and $25 \%$ of population have a regular experience with second housing activities (Fialová 2000, Vágner, Fialová 2004, Fialová, Vágner 2005a). Regional differentiation of second housing is quite big, regarded both total amount (highest number and density in the hinterland of agglomerations, in Česká Lípa and Jablonec n. N. districts - see fig. 3) and qualitative approach - old tramping settlements from the pre-World War I era in the river valleys, weekend houses localities in open scenery from the 1970s mostly, cottage villages in non-completed border and inner periphery settlements abandoned in the socialist industrialization era and as a result of the directive central settlement structure (Fialová 2001, Vágner, Fialová et al. 2004, Fialová, Vágner 2005b).

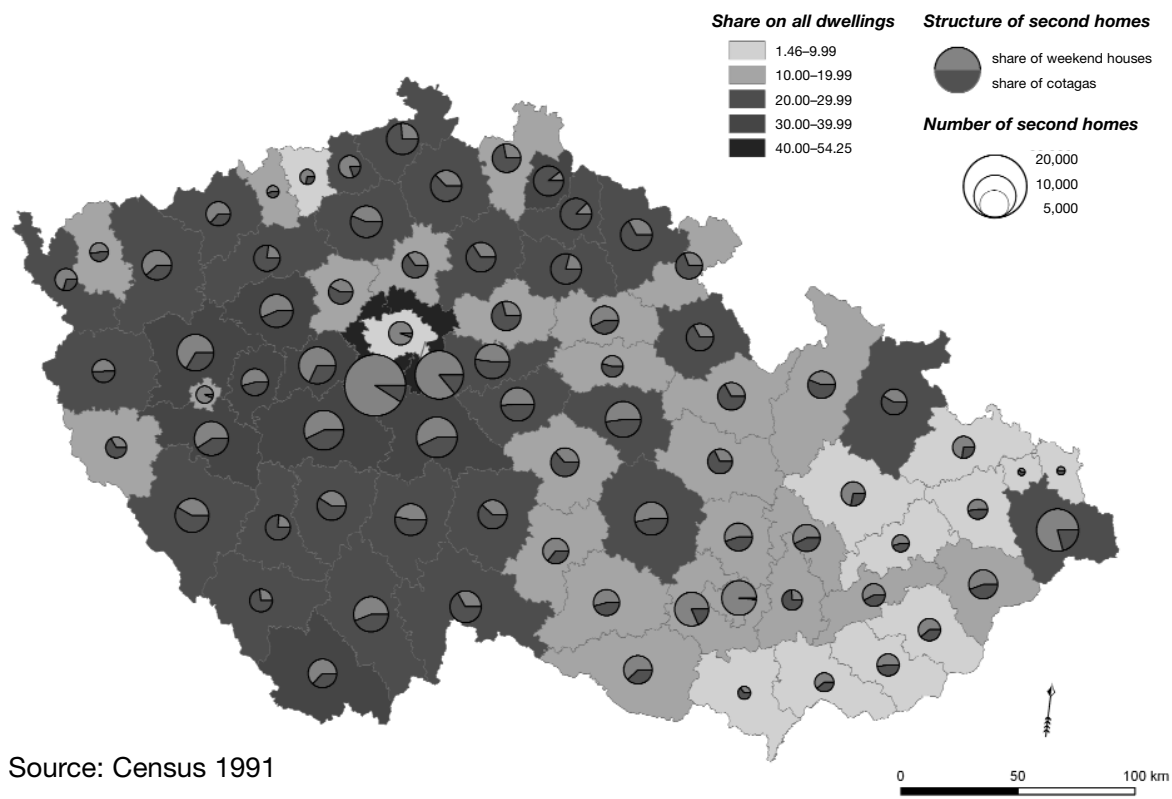

Fig. 3 The share of second homes on all dwellings

Source: Vágner, Fialová 2009

Despite some specific features of particular types, second homes frequently represent a crucial share of tourist function of some settlements and even whole regions (Defert tourist function - relation between visitors and residents (Pearce 1987).

Second housing is a typical subject of multidisciplinary interests. Besides geographers focusing directly on second home research (Gardavský 1968, Coppock, Duffield 1975, 
Kowalczyk 1994, Bičík et al. 2001, Hall, Müller 2004, Müller 2004, Vágner, Fialová et al. 2004), interest in other disciplines has been evident - psychology and sociology (e.g. Ruppert 1973, Jaakson 1986, Dingsdale 1986, Williams, Montanami 1995, Librová 1996a, 1996b, 2003, Keller 2000, Duffková 2002), ecology (e. g. Weaver 2001, Staňková 2006, Jehlička, Smith 2007), economy (e. g. Wolfe 1977, Kostelecký, Nedomová, Vajdová 1998, Gallent-Tewdr-Jones 2000), urbanism (e. g. Aldskogius 1969, Kotačka 1993, Mejsnarová et al. 2001, 2004, Horská, Maur, Musil 2002), architecture (Škabrada, 2005, 2007, Švácha 2007), even historic approach (Bačvarov 1996, Trypesová 2004). Second housing has undergone several development periods since the roots in the 1920s. Last almost two decades are the period of transition with frequent conversion into residential dwelling - an example of amenity migration (Moos 2003, cit. Pásková 2003 and rise of new forms approaching to commercial tourism (leases of second homes, new recreational villages, holiday parks, recreational apartments, time-sharing (Fialová, Kadlecová 2007, Fialová, Kadlecová, Nožičková, Vágner 2007). These processes have brought many both positive and negative changes into physical and social settlement structure (may be followed on the base of topical land use changes data (Bičík, Kupková 2006, Štych 2007).

Tourism (represented mostly with second housing in our research) belongs to dynamically developing fields, also with rapid negative impulses of natural and socioeconomic character. Contribution of tourism, besides economic benefits for local entrepreneurs and institutions, should be also reflected in the changes of functions of settlement structure and landscape. Tourism and recreation have become an integral component of lifestyle and leisure of major part of population.

Settlements/municipalities/regions with dominant tourist function either based on second homes or commercial tourist forms may be considered tourist destinations (Pásková, Zelenka 2002), playing an important role in the identity of regions. Time (stage of evolution) is a major component (TALC - Butler's tourist area lifecycle). A destination goes through stages of exploration, engagement, consolidation, stagnation and post-stagnation with options of rejuvenation, stabilization or decrease (Butler 1980). This concept offers four basic functions which are applied in practice in destination management but can be also used at both theoretical and applied level. They are called descriptive, explanatory, predictive and prescriptive functions. According to the destination position in this cycle the Doxey irritation index can be derived, demonstrating one of the internal relations in the complex of the territory users (Doxey 1975).

\section{Conclusion - a need for behavioral approaches}

Attitudes of residents to visitors (second homes owners included) are under discussion, related to the type of their mutual interaction (euphoria, apathy, disgust, antagonism). These attitudes are often regularly changing in the course of the destination lifecycle (Pásková, Zelenka 2002) and considerably influence both the intensity of regional identity and mostly identity of the regions. Implementation of behavioral approaches is an appropriate method to get ideas about attitudes. 
Behavioral geography represents one of important currents in socioeconomic geography (e. g. Hägerstrand 1967, Mansfeld 1992), which has been rather omitted and underestimated, with some exceptions (more about Czech behavioral geography Drbohlav 1993). A research objective of the behavioral geography is to observe human behavior in space and search psychological factors which influence such a behavior, to reveal types of cognitive processes and join them with following reactions at impulses from the surrounding environment. Attitudes of residents to visitors and evolution of this relationship in time and space represent an appropriate research subject. Behavioral geography can thus enrich standard, often too statistic (quantitative), views at phenomena surveyed by socioeconomic geography, with a new qualitative dimension. Behavioral geography emphasizes psychological background of human spatial behavior and point out the role of cognitive and decisive factors influencing at relations between multi-dimensional environment and human activities. Perception is defined as an active mental process of obtaining knowledge about different localities (The Dictionary of Human Geography 2000). Perception of the regional space is an essential field of study. The perception can differ for various regional actors - residents, visitors, holiday-makers etc. Different perception of these groups of actors influences considerably at spatial behavior and decisive process in the locality and therefore also influenced at process of forming of territorial identity. The research proves the importance of different, not only quantitative, but also qualitative approaches. To conclude, we outline new research objectives which will be testified in the next two years' survey:

1. Theoretical level - research on second housing (cottage activities) and other forms of tourism in the relation to forming of regional identity and identity of regions within the framework of "new" regional geography, research on geographical differentiation of regional identity of Czech population and studies of mechanisms of forming regional identity and identity of region and causality of its hierarchical order. Another objective is an analysis of the process of the institutionalization of the regions and their ability to regulate in accordance with sustainable development changes of geographical environment provoked with the development of tourism (mostly with the examples of selected model regions which represent different types of spatial polarization).

2. Applied level - verification of the following hypotheses is supposed:

a) Intensity of regional identity of territory users moves in the whole spectrum scale. Second home owners tend to identify themselves tighter than the residents with the territory than the residents in regions with minimal share of autochthonic population.

b) Regions with arguable strong regional identity of the territory users demonstrate more attempts at respect of sustainable development principles. Social and environmental component of sustainable development is weakened for the benefit of the economic component in regions with lower identity.

c) The identity of regions has not contributed sufficiently to the instruments of destination.

d) Municipalities with dominant tourist function (50\% and more dwellings serve for recreation) are frequently endangered in fulfilling of their basic function 
(self-government etc.). The way out may be seen in joining the municipality life of all territory users (second home dwellers as well).

e) Ecological advantages of peripheral regions together with the development of information technologies support increasing motivation for amenity migration of specific population groups (tertiary educated young families, wealthier younger seniors).

f) Intensive tourist function (also represented with total number of second homes) can cause a barrier.

3. Third level - discussion of conclusions from the research on regional differentiation of the role of the tourist function towards the research on regional identity and identity of regions with more general research framework. An analysis of results of the research in line with other surveys conducted at the department of social geography and regional development at the faculty of Science, Charles University in Prague - research on spatial polarization, periphery and landscape changes (land use/land cover), surveys on new trends of second housing etc.

\section{References}

ALDSKOGIUS, H. (1969): Modelling the Evolution of Setlement Patterns. In: Geografiska Regionstudier, 6.

BAČVAROV, M. (1996): Cultural Tourism in the Heritage Settlements. In: Problemy Geografijata, 1, p. 42-56.

BAKER, A. R. H. (2003): Geography and History. Bridging the Divide. Cambridge Studies in Historical Geography. Cambridge University Press, Cambridge, 279 p.

BIČÍK, I. a kol. (2001): Druhé bydlení v Česku. Katedra sociální geografie a regionálního rozvoje PřF UK v Praze, Praha, $197 \mathrm{p}$.

BIČÍK, I., KUPKOVÁ, L. (2006): Vývoj využití ploch v Pražském městském regionu. In: Ouředníček, M. ed. Sociální geografie Pražského městského regionu. Univerzita Karlova v Praze, Přírodovědecká fakulta, KSGRR, p. 42-63.

BUTLER, R. W. (1980): The Concept of Tourism Area Cycle of Evolution: Implication for Management of Resources. Canadian Geographer 24, p. 5-12.

CíLEK, V. (2007): Chatařství jako fenomén, mentalita a osud. In: Zapletalová, V. (2007): Chatařství. Architektura lidských snů a možností. Era Brno, p. 379-399.

DINGSDALE, A. (1986): Ideology and Leisure under Socialism: The Geography Second Homes in Hungary. In: Leisure Studies, 5, 1, p. 35-55.

DOXEY, A. (1975): Causation Tudory of Visitor-Resident Irritans; Metodology and research Inference, Paper Tiber at San Diego, California, The Travel research Association Conference no. 6,

DRBOHLAV, D. (1993): Behaviorální př́stup v geografii. In: Sýkora, L., Teoretické př́stupy a vybrané problémy v současné geografii. Praha, KSGRR, p. 31-41.

DUFFKOVÁ, J. (2002): První a druhý domov: Vývoj české záliby v chataření a chalupaření z pohledu sociologie. Př́tomnost, č. 7.

FIALOVÁ, D. (2000): Transformace druhého bydlení v Česku (na př́kladu zázemí Prahy). Dizertační práce. UK PřF KSGRR Praha, $130 \mathrm{p}$.

FIALOVÁ, D. (2001): Druhé bydlení a jeho vztah k periferním oblastem. Geografie - Sborník ČGS, 106, č. 1, p. $36-47$.

FIALOVÁ, D., VÁGNER, J. (2005a): Struktura, typologie, současnost a perspektivy druhého bydlení v Česku. Geografie - Sborník ČGS, 109, č. 2, ČGS, Praha, p. 73-81.

FIALOVÁ, D., VÁGNER, J. (2005b): Druhé bydlení v periferních oblastech. In.: Novotná, M. ed.: Problémy periferních oblastí. KSGRR PřF UK, Praha, p. 74-80. 
FIALOVÁ, D., KADLECOVÁ, V. (2007): Nové trendy a dopady druhého bydlení. In: Kraft, S., Mičková, K., Rypl, J., Švec.P., Vančura, M., eds. Česká geografie v Evropském prostoru. Sborník XXI. Sjezdu České geografické společnosti, JČU PedF České Budějovice, p. 36-41.

FIALOVÁ, D., KADLECOVÁ, V., NOŽIČKOVÁ, V., VÁGNER, J. (2007): Changes in second housing in the integrating Europe. In: Wilk, W. (ed): Global changes: their regional and local aspects. FGRS Warsaw University, Warszawa, v tisku.

GALLENT, N., TEWDWR-JONES, M. (2000): Rural second homes in Europe. Ashgate, 166 p.

GARDAVSKÝ, V. (1968): Rekreační zázemí Prahy. Kandidátská disertační práce. PřF UK Praha, 91 p.

GESLER, W. M., KEARNS, R. A. (2002): Culture/Place/Health. Routledge, London and New York, p. 19-20.

GRAHAM, B. (2000): The past in place: historical geographies of identity. In: Graham, B., Nash, C. (Eds.): Modern Historical Geographies. Pearson Education Ltd., Harlow, p. 70-99.

GRAHAM, B., NASH, C., eds. (2000): Modern Historical Geographies. Pearson Education Ltd., Harlow, $279 \mathrm{p}$.

GUSTAFSON, P. (2001): Meanings of Place: Everyday Experience and Theoretical Conceptualizations. Journal of Environmental Psychology, 21, p. 5-16.

HÄGERSTRAND, T. (1967): Innovation Diffusion as a Spatial Process, University of Chicago, 339 p.

HALL, C. M., MÜLLER, D. K. (eds.) (2004): Tourism, Mobility and Second Homes. Aspects of Tourism, 15, Channel View Publications, $304 \mathrm{p}$.

HAMPL, M. a kol. (1996): Geografická organizace společnosti a transformační procesy v České republice. Př́rodovědecká fakulta Univerzity Karlovy, Praha, 395 p.

HAMPL, M. a kol. (2001): Regionální vývoj: specifika české transformace, evropská integrace a obecná teorie. Univerzita Karlova v Praze, Přírodovědecká fakulta, katedra sociální geografie a regionálního rozvoje, Praha, 328 p.

HAMPL, M. (2003): Diferenciace a zvraty regionálního vývoje Karlovarska: unikátní případ nebo obecný vzor? Geografie - Sborník ČGS, 108, č. 3, ČGS, Praha, p. 173-190.

HEŘMANOVÁ, E., CHROMÝ, P. a kol. (2009): Kulturní regiony a geografie kultury. ASPI, Praha, 348 p.

HOLDSWORTH, D. W. (2002): Historical geography: the ancients and the moderns - generational vitality. Progress in Human Geography, 26, 5, p. 671-678.

HORSKÁ, P., MAUR ,E., MUSIL, J. (2002): Zrod velkoměsta: Urbanizace českých zemí a Evropa. Paseka Praha.

CHROMÝ, P. (2000): Historickogeografické aspekty vymezování pohraničí jako součást geografické analýzy. Geografie - Sborník ČGS, 105, č. 1, p. 63-76.

CHROMÝ, P. (2003): Formování regionální identity: nezbytná součást geografických výzkumů. In: Jančák, V., Chromý, P., Marada, M. (Eds.): Geografie na cestách poznání. Sborník př́íspěvků k šedesátinám Ivana Bičíka. Univerzita Karlova v Praze, Přírodovědecká fakulta, katedra sociální geografie a regionálního rozvoje, Praha, p. 163-178.

CHROMÝ, P. (2004a): Historická a kulturní geografie a nové př́stupy v regionálním studiu. Dizertační práce. Univerzita Karlova v Praze, Př́rodovědecká fakulta, katedra sociální geografie a regionálního rozvoje, Praha, 60 p. + encl.

CHROMÝ, P. (2004b): Kdyby byla Morava... Geografie - Sborník ČGS, 109, č. 1, p. 66-69.

CHROMÝ, P., JANŮ, H. (2003): Regional identity, activation of territorial communities and the potential of the development of peripheral regions. Acta Universitatis Carolinae Geographica, 38, No. 1, p. $105-117$.

CHROMÝ, P., KUČEROVÁ, S., KUČERA, Z. (2009): Regional Identity, Contemporary and Historical Regions and the Issue of Relict Borders. The Case of Czechia. Regions and Regionalism, 9, 2, p. 9-19.

JEHLIČKA, P., SMITH, J. (2007): Out of the Woods and into the Lab: Exploring the Strange Marriage of American Woodcraft and Societal Ecology in Czech Environmentalism. Environment and History, 13, The White Horse Press, p. 187-200.

KELLER, J. (2000): Vzestup a pád středních vrstev. Sociologické nakladatelství SLON. Praha.

KOSTELECKÝ, T., NEDOMOVÁ, A., VAJDOVÁ, Z. (1998): Trh s bydlením a jeho sociální souvislosti situace v Praze a Brně. Working Papers 1998, 1, Sociologický ústav AV ČR.

KOTAČKA, L. (1993): Hlavní tendence vývoje osídlení v západní Evropě a jejich implikace pro vývoj osídlení u nás. In: Výstavba a architektura, 39, č. 6, VÚVA, Praha, p. 3-9. 
KOWALCZYK, A. (1994): Geograficzno-spoleczne problemy zjawiska „drugich domow“, Uniwersytet Warszawski, $179 \mathrm{p}$.

KUČERA, Z. (2007): Zanikání sídel v pohraničí Čech po roce 1945 - základní analýza. Historická geografie, 34, p. 317-334.

LIBROVÁ, H. (1996a): Decentralizace osídlení - vize a realita. Část první: vize, postoje k venkovu a potenciální migrace v ČR. Sociologický časopis, 32, č. 3, Sociologický ústav AV ČR, Praha, p. 285-296.

LIBROVÁ, H. (1996b): Decentralizace osídlení - vize a realita. Část druhá: decentralizace v rámci České republiky. Sociologický časopis, 33, č. 1, Sociologický ústav AV ČR, Praha, p. 27-40.

LIBROVÁ, H. (2003): Vlažní a váhaví - Kapitoly o ekologickém luxusu. Doplněk Brno.

MANSFELD, Y. (1992): Tourism:Towards a Behavioural Approach. In: Progress in Planning, 38, Pergamon Press, New York.

MITCHELL, K. (2004): Geographies of identity: multiculturalism unplugged. Progress in Human Geography, 28, 5, p. 641-651.

MEJSNAROVÁ, J. et al. (2001): Letní rekreační potenciál ČR. FA ČVUT v Praze. Zpracováno pro odbor MMR ČR v Praze.

MEJSNAROVÁ, J. (2004): Druhé bydlení z pohledu územně-plánovací praxe - návštěvnost chatových osad v zázemí Prahy. In: Vágner, J., Fialová, D. a kol. (2004): Regionální diferenciace druhého bydlení v Česku. Edice UK PřF KSGRRR, p. 177-183.

MÜLLER, D. K. (2004): Mobility, Tourism and Second Homes. In: Lew, A. A., Hall, C. M., Williams, A. M.: A Companion to Tourism. Blackwell Publishing, p. 387-398.

NASH, C. (2002): Cultural geography: postcolonial cultural geographies. Progress in Human Geography, 26, 2, p. 219-230.

NASH, C. (2003): Cultural geography: anti-racist geographies. Progress in Human Geography 27, 5, p. 637-648.

PAASI, A. (1986): The institutionalization of regions: a theoretical framework for understanding the emergence of regions and the constitution of regional identity. Fennia, 164, č. 1, Helsinki, p. 105-146.

PAASI, A. (2002): Place and region: regional worlds and words. Progress in Human Geography, 26, 6, p. 802-811.

PÁSKOVÁ, M., ZELENKA, J. (2002): Výkladový slovník cestovního ruchu. MMR ČR, Praha, p. 448.

PÁSKOVÁ, M. (2003): Analýza změn vyvolaných rozvojem cestovního ruchu ve světle kriticko-realistické metodologie. Dizertační práce. KSGRR PřF UK, Praha, 205 p.

PEARCE, D. (1987): Tourism Today: a Geographical Analysis. Longman Scientific and Technical, New York.

ROBERTS, K. (2002): Leisure in Contemporary Society. CABI Publishing, 250 p.

RUPPERT, K. (1973): Geographische Aspekte der Freizeitwohnsitze, WGI Berichte zur Regionalforschung, $11, \mathrm{M}(\mathrm{nchen}, \mathrm{p} .8-19$.

SIWEK, T. (1996): Česko-polská etnická hranice. Ostravská univerzita, Filozofická fakulta, Ostrava, 96 p., 21 map.

SIWEK, T. (1999): Příspěvek ke zkoumání etnické hranice. Geografie - Sborník ČGS, 104, č. 1, p. 1-12.

SIWEK, T., KAŇOK, J. (2000): Vědomí slezské identity v mentální mapě. Ostravská univerzita, Filozofická fakulta, Ostrava, 98 p., 2 mapy.

Stanovisko geografů, jazykovědců, historiků a pracovníků dalších vědních oborů k otázce oficiálního jednoslovného geografického názvu pro Českou republiku. In: Geografické rozhledy, 7, 1997/98, č. 4, p. 99-100.

STAŇKOVÁ, J. (2006): Vybrané aspekty turistiky a udržitelného rozvoje v Národním parku Šumava a v Národním parku Podyjí z pohledu tří skupin respondentů. Disertační práce, ÚOŽP PřF UK, Praha, $132 \mathrm{p}$.

ŠKABRADA, J. (2005): Lidové stavby - Architektura českého venkova. ARGO, 246 p.

ŠKABRADA, J. (2007): Nemám rád chaty - chaty proti lidové architektuře. In: Zapletalová, V. (2007): Chatařství. Architektura lidských snů a možností. Era Brno, p. 365-368.

ŠTYCH, P. (2007): Územní diferenciace dlouhodobých změn využití krajiny Česka. Disertační práce. KSGRR PřF UK, Praha, 128 p.

ŠVÁCHA, R. (2007): Chaty jako architektura. In: Zapletalová, V. (2007): Chatařství. Architektura lidských snů a možností. Era Brno, p. 369-378. 
TRYPESOVÁ, P. (2004): The Subculture of Weekend House Holders in Czechoslovakia: 1950-89. International Oral History Association Newsletter, Number 12:1, 2004.

VÁGNER, J., FIALOVÁ, D. a kol. (2004): Regionální diferenciace druhého bydlení v Česku. Edice UK PřF KSGRR Praha, 286 p.

VÁGNER, J., FIALOVÁ, D. (2009): Podíl objektů druhého bydlení na úhrnu staveb. In: Hrnčiarová, T., Mackovčin, P. a kol.: Atlas krajiny České republiky. Ministerstvo životního prostředí ČR a Výzkumný ústav Silva Taroucy pro krajinu a okrasné zahradnictví, v.v.i., Praha-Průhonice, v tisku.

VENCÁLEK, J. (1998b): Protisměry územní identity. 1. vyd. Olza, Český Těšín, 208 p.

WEAVER, D. (ed.) (2001): The Encyklopedia of Ecotourism. COBI Publishing London, 668 p.

TUAN, Y.F. (2001): Space and Place (new edition). University of Minnesota Press, 248 p.

WILLIAMS, A. M., MONTANAMI, A. (1995): Tourism Regions and Spaces in a Changing Social Framework. TESG Utrecht, Vol. 86, 1, 110 p.

WOLFE, R. I. (1977): Summer Cottages in Ontario: Purpose-built for an Inessential Purpose. In: Coppock, J. T. (ed.): Second Homes: Curse or Blessing? Pergamon Press, p. 17-33.

ZEMAN, K. (2001): Vliv hranic na př́ihraniční území na př́kladu Jindřichohradecka. Magisterská práce. Katedra sociální geografie a regionálního rozvoje PřF UK, Praha, 150 p.

ZICH, F., ed. (2003): Regionální identita obyvatel pohraničí. Sborník příspěvků z konference „Evropská, národní, či regionální identita?“, Praha 3. 10. 2003. Sociologický ústav AV ČR, Praha, 262 p.

\section{Résumé}

\section{Formování regionální identity a identity regionů v Česku - představení výzkumu vlivu druhého bydlení a cestovního ruchu}

Předložený článek je založen především na diskusi teoretických př́stupů a vybraných konceptů nové regionální, kulturní a behaviorální geografie, které mohou být využity při výzkumech druhého bydlenî a cestovního ruchu. Důraz je kladen na obecné a metodologické pohledy na procesy formování regionální identity a identity regionů $\mathrm{v}$ území s výraznou koncentrací sídel a obcí s převažující rekreační a turistickou funkcí. Žádoucí součástí výzkumů je identifikace vnitřního socioekonomického a sociokulturního potenciálu lokalit a regionů. $\mathrm{S}$ vnější i vnitřní identitou regionů nedílně souvisí regionální povědomí sounáležitosti rezidentů, ale i rekreantů a turistů. Hlavním cílem je podpořit a vysvětlit možnosti využití behaviorálních př́stupů ve výzkumech vlivu druhého bydlení a turistických aktivit na formování regionální identity a identity regionů.

RNDr. Dana Fialová, Ph.D., RNDr. Pavel Chromý, Ph.D., RNDr. Zdeněk Kučera, RNDr. Jana Spilková, Ph.D., RNDr. Jiř́ Vágner. Ph.D. Department of Social Geography and Regional Development Charles University in Prague Faculty of Science Albertov 6

12843 Prague 2 e-mail: danafi@natur.cuni.cz,chromy@natur.cuni.cz,kucera12@natur.cuni.cz, spilkova@natur.cuni.cz,vagner@natur.cuni.cz

RNDr. Přemysl Štych, Ph.D. Department of Applied Geoinformatics and Cartography Charles University in Prague

Faculty of Science Albertov 6

12843 Prague 2

e-mail: stych@natur.cuni.cz 